\title{
A Study of Olang Bubega Silat Changes from Tradition to Entertainment Arts in the Community Wedding Ceremony in Rokan Hulu Regency, Riau
}

\author{
$1^{\text {st }}$ Santi Mustika Rani \\ Social Science Education \\ Concentration in Cultural Arts \\ Graduate Student of Universitas Negeri Padang \\ Santimustikarani23@gmail.com
}

\author{
$2^{\text {nd }}$ Fuji Astuti* \\ Social Science Education \\ Concentration in Cultural Arts \\ Graduate Student of Universitas Negeri Padang \\ astuti@fbsunp.co.id
}

\begin{abstract}
This research was aimed at subscribing and analyzing the changes of Olang Bubega silat from tradition to entertainment arts in the community wedding ceremony. This type of research was qualitative by using a descriptive method. The object of this research was Olang Bubega silat. The data were collected by using literature review, observation, interview and documentation. The data were analyzed by reduction, data collection, and verification, then the conclusion was drawn by using interpretation techniques so that the truth or
\end{abstract}

\section{INTRODUCTION}

Riau Province is part of the territory of Indonesia which is inhabited by a variety of diverse tribes, from various tribes there are also various customs and traditions, the culture of each of these tribes has distinctive features that are the pride of the region itself. This is proven by the diversity of cultures and customs of the creations of the ancestors who have very high values, even cannot be measured by material values. Similar to the culture in one regency in Riau province, Rokan Hulu regency which has a culture, one of which is in the Rambah Hilir Sub-District, namely Olang Bubega silat culture, which has become an art of entertainment at weddings of Malay tribal communities.

Social changesare changes that occur in the structure and function of society [1]. Martial arts are used at meetings between ninik mamak, while in the entertainment arts are validity could be obtained. The results of this research showed that the changes of Olang Bubega silat from tradition to entertainment arts could be seen from the presentation requirements, form of presentation which included motion, costume, property, and accompaniment music. The Olang Bubega silat tradition is rarely shown, but currently it is used as an entertainment art for the Muara Musu community, which is often shown in a wedding ceremony.

Keywords-Olang Bubega Silat, Changes, Tradition, Entertainment

used at wedding ceremonies. One of the functions of carrying out traditional ceremonies (oral traditions) is as ceremonial ceremonies, namely to mark the state of crisis in group life. The implementation of traditional ceremonies are served to reduce the fear of crisis, mobilize collective activities, and as a place to unite people [2]. Then, it can also be seen from the form of presentation, and the Olang Bubega silat performers found at the wedding ceremony in Muara Musu village, Rambah Hilir Sub-District, Rokan Hulu Regency, Riau Province, which is developing at this time. To see the change of Olang Bubega silat from tradition to the art of entertainment or seen from several components which include presentation requirements, forms of traditional presentation (movements, costumes, properties, accompaniment music), functions and silat performers. Meanwhile, Olang Bubega silat from entertainment arts at the wedding ceremony will be distinguished in 
the form of presentation which includes motion, costumes, property, accompaniment music, as well as functions, and silat performers.

The changes in culture will penetrate into various aspects of existing culture and the culture is constantly changing [3]. The Olang Bubega silat was originally used for selfdefense and was displayed at the traditional datuk meeting, but along with the times there was a change in function where the Olang Bubega silat became a means of entertainment that was displayed in the middle of the open field in the area of the marriage and accompanied by music played by musicians at a wedding ceremony among the Malay community of Muara Musu village, Rambah Hilir Sub-District, Rokan Hulu district. Before Olang Bubega silat tradition was displayed at the traditional datuk meeting there were several presenting conditions that had to be fulfilled by the fighter, while in Olang Bubega silat when it was displayed at the wedding ceremony there were no more special requirements that must be fulfilled by the fighter. The changes and shifts are based on the ruler who is the center of power that can provide safety, welfare, and happiness to the people in their environment [4]. The number of traditional martial arts actors at the traditional Datuk meeting is two adult males while the number of Olang Bubega silat fighters displayed at the wedding ceremony is still two men but not necessarily adult men but may be done by children who memorize by movement Olang Bubega silat parried. However, this performance is taking place the Pesilat perform movements according to the accompaniment of music played by musicians. Festivals in traditional Olang Bubega silat are only done by two adult men because in this traditional Olang Bubega silat there are practices that must be done and should not be violated, therefore it should only be done by adult men who can already think of the consequences if violate these practices. Nevertheless, Olang Bubega silat at the wedding ceremony there is no practice, therefore it is permissible for two children to memorize the bubega parried silat. The shift of nuance or culture is essentially a form of transformation that follows the times and the thoughts of the copyist [5].

\section{METHOD}

This research was a qualitative study using a descriptive analysis method. The object of the research was Olang Bubega silat from Rambah Hilir Sub-District, Rokan Hulu Regency, Riau Province. The research method was a scientific way to obtain the data and specific goals and uses [6]. The researcher conducted research in Muara Musu village, Rambah Hilir Sub-District because the researcher was from Muara Musu village.In Muara Musu village, there was a traditional art, namely Olang Bubega silat, which at this time many young people do not know about the Olang Bubega silat. Therefore, Olang Bubega silat was used as a means of entertainment at the Malay wedding community in Rambah Hilir Sub-District. There were 9 informants in this research including 1 creator of Olang Bubega Tradition, 1 creator of Olang Bubega Entertainment, 1 traditional figure, 2 members of Olang Bubega Tradition, 2 people in Muara Musu village, 1 musician of Olang Bubega silat, and 1 performer of the Olang Bubega martial entertainment art.

The data collection techniques were carried our by using literature review, observation, interviews and documentation. The observations used by researchers were nonparticipatory observations. In this research, the researcher was not directly involved in the implementation of the silat performance. The researcher only observed directly to the area of research object, namely the study of the change of Olang Bubega silat from tradition to the entertainment art at the Malay wedding ceremony in Rambah Hilir Sub-District, Rokan Hulu Regency, Riau Province. In this observation technique the researcher observed the Olang Bubega Silat from Tradition to the Entertainment art at a Malay Community Wedding Ceremony in Rambah Hilir SubDistrict, Rokan Hulu Regency, Riau Province. The researcher recorded, analyzed, and then made conclusions from the data found in the field. 
The next stage was conducting interviews to collect data by asking questions verbally to the research subjects or informants. This instrument was used to obtain information about facts, beliefs, feelings, intentions, and so on. In this research, the interview used by the researcher was directional or structured interview. Through this technique the researcher conducted activities in the form of question and answer directly to the informants, namely Mr. Samsul Bahari and Salim who knew about Olang Bubega silat by bringing a complete set of directed and detailed questions by interviewing in detail live.

In this research, the researcher used a digital camera in video shooting and photographs of traditional forms of Olang Bubega Silat presentation, Olang Bubega silat structure in the entertainment art, and Olang Bubega silat presentation at the Malay wedding ceremony in Rambah Hilir Sub-District, RokanHulu Regency Riau. Therefore, this aims to make it easier for writers who will process data and to strengthen the results of research by the author.

The datawere analyzed by reduction, data collection, and verification, then conclusions were drawn with interpretation techniques so that truth or validity can be obtained. The results of this research indicated that the transformation of the Olang Bubega silat from Tradition into entertainment art can be seen from the requirements of presentation, the form of presentation which includes motion, costumes, aaccompanying property and music. Thus, the researcher analyzed the decision making and verification data because the researcher tried to take the main things about Olang Bubega Silat from Tradition to the of Entertainment art at the Malay Community Wedding Ceremony in Rambah Hilir SubDistrict, Rokan Hulu Regency, Riau Province. Then, with the data obtained in the field the researcher analyzed, drew conclusions, and described it in writing as research. This was done to be able to find answers to problems raised by researchers.

\section{RESULTS AND DISCUSSION}

\section{The changes of Olang Bubega silat from tradition to entertainment is viewed from the presentation and function requirements}

The changes occurred can be seen from the presentation requirements. In the form of tradition, Olang Bubega silat has special requirements in doing it, which is to mix lime, then the lime is mixed with plain water then bathed to the performers, and finally the wages are aimed at to treat mentally or spiritually so they cannot get sick. Nevertheless, Olang Bubega silat in the art of entertainment at weddings does not use certain conditions in doing the martial arts, silat. As it was seen in terms of the function which in the form of Traditional Olang Bubega silat function was self-defense and could also heal the sick, while the Olang Bubega silat function in the art of entertainment at weddings as a tribute or welcome to the bride of men who come to the bride of a bride. The performers of silat in every performance who do silat must shake hands first with Datuk at the event.

\section{The changes of Olang Bubega silat from tradition to entertainment is viewed from the form of presentation and performers of silat}

The changes can be seen also from the form of presenting Olang Bubega silat in the form of Tradition with Olang Bubega silat in the art of entertainment at weddings which includes motion, costumes, property and accompaniment music. Olang Bubega silat in the tradition, there were only 3 movements of silat style, while in Olang Bubega silat in the entertainment art, it has been developed into 13 kinds of silat movements without eliminating 3 kinds of movements from Olang Bubega silat. 
Table 1. The Variety of Olang Bubega Silat in the Form of Tradition and Entertainment Art at a Wedding

\begin{tabular}{ll}
\hline $\begin{array}{l}\text { The Variety of the Olang Bubega Silat } \\
\text { Traditional Movements }\end{array}$ & $\begin{array}{l}\text { The Variety of the Olang Bubega Silat } \\
\text { Movements in the Entertainment Art }\end{array}$ \\
\hline 1. Sembah & 1. Sembah \\
2. Burobah Bupulon, & 2. Burobah Bupulon, \\
3. Olang bubega & 3. Tariek Rotan Purodeh \\
4. Anak Simuo. & 4. Olang Bubega \\
& 5. Sirieh Sukapuo \\
& 6. Tunggang Gurigiek \\
& 7. Langkah Meragukan Lawan \\
& 8. Tupai Bugoluik \\
9. Pancong \\
10. Muhago Lawan \\
11. Menipu lawan \\
12. Tikam 5 Tari \\
13. Anak Simuo.
\end{tabular}

The symbol as a social object in an interaction, it is used as a representation and communication determined by the people who use it. The person gives meaning to create and change physical objects (objects), words (to represent physical objects, feelings, ideas and values) and actions taken by people to give meaning in communication with others [7]. The first movement is the gesture of prayer meant to give honor to the groom and his entourage and give honor to the invited guests who came to attend the event. Before performing any silat, the silat fighters first shakes hand to the groom as well as Olang Bubega silat before shaking the traditional Datuak as a sign of respect and signifying that silat will soon begin. The gesture was shown when the fighter's hand clasped his two hands and worshiped.

The second motion Bupulon Burobah movement is a movement that is imitated from the fight birds. This movement means that there has been resistance between the fighters and each other, which has begun to enter the fight stage. When you have entered at this stage the silat must begin to be careful and install sturdy horses so that they are not easily defeated by opponents. movements such as birds fighting as seen from the form of Burobah Bupulon movement where the position of the pesilat is sitting with his hands up and down about to start fighting.

The next movement of Olang Bubega is a movement that symbolizes the eagle is looking for prey while spinning before pouncing on its prey until it can. Usually, this eagle quarries first, after the opponent or prey is not focused, then immediately pounced. This movement is taken from the imitation of an eagle that is pouncing on its prey. The shape of Olang Bubega movement can be seen from its flanking movement as if it wants to fly, reflecting like an eagle.

The next movement is SiriehSukapuo Movement, a movement carried out by giving a battle to the groom and to the invited guests who come to the wedding. The betel movement is a movement where we give the betel to the groom, in addition to as a sign of respect to give a battle as well as a sign that welcome and congratulations on joining a new family. This movement is seen in motion with the position of the legs of the left hand in the hand while the right hand takes something from inside the left hand and is given to the groom or spectator as a tribute.

The next movement is Anak Simuo Movement which is the closing variation movement of all the movements that exist in Olang Bubega silat. This movement ends with a 
movement like worshiping at the first move, which means goodbye because Olang Bubega silat has been completed. The costumes used when performing traditional Olang Bubega silat are black shirts with long sleeves, long pants, wearing side cloths and wearing black skullcap or skullcap. Meahwhile, the costumes worn when doing Olang Bubega silat at the wedding ceremony have changed to no longer use costumes like doing Traditional Olang Bubega silat. The costumes used by Olang Bubega silat performers in the art of entertainment at weddings, namely free clothes, do not have to be black, which is neat, polite and comfortable so that the silat performers are more free to do the silat movements, besides using side cloths and skullcap.

Table 2. The Costumes of Traditional Olang Bubega Silat and the Olang Bubega Silat in Entertainment Art

\begin{tabular}{cc}
\hline The Traditional Olang Bubega silat & The Olang Bubega silat Costume in \\
Costume & Entertainment Art
\end{tabular}
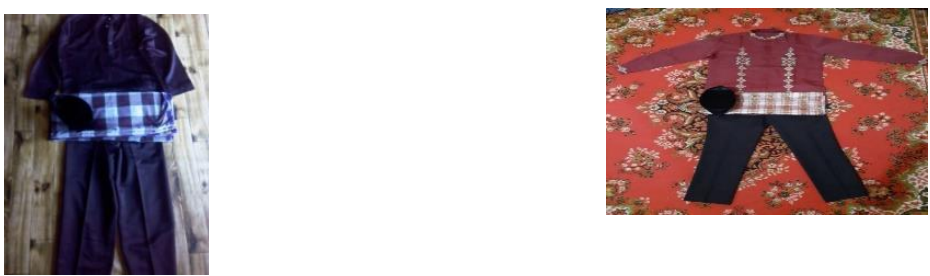

Property is a tool used by dancers in performing a performance. Property itself has the meaning of equipment that is brought or played when a dancer or fighter performs a performance. Properties used in traditional Traditional Olang Bubega silat can be small knives and long swords. Meanwhile, Olang Bubega silat on the wedding depends on agreement by the host, if the host wants the fighter to use the property, the fighter uses the property, but if the host does not want the fighter to use the property in conducting the silat, the fighter does not use the property. Most at this time the perpetrators of silat in conducting Olang Bubega silat at weddings are no longer using property for fear of endangering the perpetrators of silat. Then Seen from the musical accompaniment of Olang Bubega silat, the musical instrument used as an accompaniment in performing the traditional Olang Bubega silat as well as the art of entertainment at the wedding ceremony took the form of 1 (one) Gong, Gendang Panjang and Celempong. How to play Gong by being hit on the top with a wooden paddle and the end covered with rubber, while the Long Drum is played by beating on 2 parts of the drum skin, and Celempong is played by being hit also on the front in accordance with the desired rhythm. The music function at Olang Bubega silat performance is as an accompaniment of the silat movements carried out by the pesilat.

The performers of Olang Bubega silat. The number of fighters or performers in the Traditional Olang Bubega silat practiced by two adult men should not be done by children because the traditional Olang Bubega silat performers have practices - practices that must be carried out by fighters such as not to get drunk should not be drunk gambling, if it is done by children it is feared that they cannot obey the practices and will violate those practices which can endanger the child itself. while Olang Bubega silat in the art of entertainment in a wedding ceremony can be done by two adult men but not necessarily adult men but may be done by children who memorize Olang Bubega silat movements. 
The public response to the existence of Olang Bubega silat, both traditional and entertaining, was very well received by the community. The meaning of Olang Bubega silat means symbolizing one's courage and dexterity with another meaning that the villagers are brave in facing all obstacles and challenges that might happen later in life, and in living this life sometimes it is not always in accordance with what it is hoped and wanted. Life is not always as smooth as what it is wanted, surely there will be challenges and obstacles that will appear any time before it can be guessed, even it is a big challenge or a small challenge. The reason the Muara Musu village community still maintains this tradition is because this is one culture that we must preserve and maintain. Besides, if it is not our own local people who defend our traditions and culture, then everyone will defend them. Then, the people want to remind the people of Muara Musu village who have migrated and stayed overseas to keep in mind the tradition of Olang Bubega silat.

The way for the community to maintain the Olang Bubega silat culture from Tradition to Entertainment Art by conducting teaching to each generation so that this silat continues and not breaking up, then the effort is to introduce Olang Bubega silat from Tradition to Entertainment Art through social media so it will not be lost by the current development. The changes of function donot change the enthusiasm of the community which can be seen when Olang Bubega silat of the Tradition and Olang Bubega silat of Entertainment Art is displayed. Many people watch and perform Olang Bubega silat.

\section{CONCLUSIONS}

Based on the results of research that has been done, it can be concluded that Olang Bubega silat in the art of entertainment at a wedding ceremony has changed. In this research, it can be seen from the changes in terms of the changes in traditional Olang Bubega silat into the art of entertainment at weddings. In accordance with the times, this silat also experienced developments and changes aimed at making this Bubega processed silat more interesting and not boring. Besides that, it also preserves Olang Bubega silat, both traditional and entertainment, so that it is not lost by the modernization. Olang Bubega silat was held at a wedding so that the wider community was more familiar with and knew about the existence of Olang Bubega silat because at the wedding event many invited guests came to see the appearance of Olang Bubega silat. These changes can be seen from the requirements of presentation, the form of presentation which includes motion, costumes, property, accompaniment music, then it can also be seen also the changes that occur on the silat performers and also the silat function.

\section{REFERENCES}

[1] S. Soekanto. (2012). Sosiologi Suatu Pengantar. Jakarta: Rajawali Pers.

[2] W. A. Haviland. (1988). Antropologi Jilid I. Jakarta: Erlangga

[3] Dariusti. (2011). Hegemoni Penghulu Dalam Perspektif Budaya (edisi revisi). Yogyakarta: Multi Grafindo.

[4] E. Sedyawati. (1980). Perkembangan Seni Pertunjukan. Jakarta: Sinar Harapan.

[5] K.Z. Istanti. (2010). Transformasi dan Integrasi dalam Kesustraan Nusantra: Perbandingan Teks Amir Hamzah Melayu dan Jawa. Humaniora: Jurnal Budaya, Sastra, \& Bahasa, 22, pp. 241-249.

[6] Sugiyono. (2011). Metode Penelitian Pendidikan. Bandung: Alfabeta.

[7] R. Soeprapto. (2001). Interaksi Simbolik Perspektif Sosiologi Modern. Yogyakarta: Averroses Press dan Pustaka Pelajar. 